\title{
The price premium of an environmentally friendly product
}

\author{
Dimitri Kapelianis \& Sandra Strachan \\ Department of Business Economics, School of Economic and Business Studies, University of the Witwatersrand, Private Bag 3, P.O. Wits. \\ 2050 Republic of South Africa
}

\author{
4.5 \\ Received August 1996
}

\begin{abstract}
The relationship between marketing and the environment has recently received considerable attention. Much of the literature in this field deals with the premia that consumers are willing to pay for environmentally friendly products as well as the characteristics that describe these consumers. The methods used for estimating these premia are, however, methodologically flawed. This article presents a model for calculating premia on the basis of part-worth utilities derived from conjoint analysis. The authors find that racial and educational differences exist in willingness to pay a premium. These differences persist even when variances in other variables (for example, income) are controlled.
\end{abstract}

Die verhouding tussen bemarking en die omgewing geniet in die laaste tyd baie aandag. ' $n$ Groot deel van die literatuur hieroor ondersoek die premie wat verbruikers bereid sou wees om vir omgewingsvriendelike produkte te betaal en beskryf die eienskappe van hierdie verbruikers. Die metodes wat gebruik word om hierdie premies te bereken, is egter nie korrek nie. Hierdie artikel beskryf 'n prosedure wat gedeeltelike nutswaardes uit saamgevoegde-analise gebruik om hierdie premies te bereken. Daar word bevind dat persone van verskillende rasse en opvoedingsvlakke bereid is om verskillende premies te betaal. Hierdie verskille bestaan ook wanneer daar vir ander veranderlikes (byvoorbeeld inkomste) gekontroleer word.

\section{Introduction}

The interface between marketing and the environment has become one of the most discussed issues in the popular marketing press. There remains, however, a dearth of solid academic research into the topic, especially in South Africa. As a result, it is hardly surprising that this discussion is characterized by unsubstantiated claims and the often shallow reporting of commercial research results. Three central themes can be found in this literature: the premium that consumers are willing to pay for an environmentally friendly product; the characteristics that describe these consumers; and the proportion of the market that these consumers represent.

We review the existing literature on this topic examining such issues as the concept of green marketing, the nature of externalities and price premia, market segmentation and market size. In the empirical section of the article, we discuss our research methodology; deal with issues of data analysis - in particular, conjoint analysis and the method used for calculating the premium of an environmentally friendly product; and we present and discuss our research results. The final section presents some suggestions for further research and our concluding comments.

\section{Literature review}

Marketing concept, societal marketing and green marketing: a brief overview

According to Bell \& Emory (1971: 38), the marketing concept is an attempt to operationalize a basic philosophy of marketing. The traditional marketing concept has at its core three essential elements: firstly, the belief that the firm should adopt a customer-driven orientation; secondly, this effort should be integrated across the entire firm; and finally, that profit maximization should be pursued as the firm's end goal. McDaniel \& Rylander point out, however, that

'questions were raised regarding whether the marketing concept leads to misplaced emphasis on customer "want" satisfaction while ignoring the long-run best interests of society and the environment' (1993: 4).
It was as a result of this line of questioning that Kotler (1976: 16-18) delineated his now famous societal marketing concept - the addition of societal welfare as a fourth tenet to the traditional marketing concept. Green marketing flows naturally from the philosophy of societal marketing. McDaniel \& Rylander (1993: 4) have defined it as marketers' attempts to develop strategies targeting the environmental consumer. It is this and more. Vandermerwe \& Oliff (1990: 10-11) indicate that 'green' has become a shorthand term for a number of issues dealing with, amongst others, resource depletion, waste emission and accumulation, and harmful products.

\section{Concept of externalities and price premia for green pro- ducts}

In the language of economists, an externality (which can be either positive or negative) occurs when a discrepancy exists between social and private benefits or social and private costs (Hirshleifer, 1988: 472). Broadly speaking, negative externalities arise when the actions of some people detrimentally affect others - and these others are not consulted to give their consent nor are they compensated should they suffer any loss. Pollution is the most widely cited example of such an externality. It is at this point that economics and green marketing are connected - the production and consumption of products that are harmful to the environment affects not only the parties to the contract but also third parties.

Traditionally, three public policy approaches to the problem of externalities have been cited (Hirshleifer, 1988: 474-475). These are tax-subsidy adjustments, unitization and property right reassignments. Firms can be taxed at a level equal to the monetary value of the negative externality. Ideally, this money would then be passed on to injured parties to compensate them for any loss incurred. Alternatively, the externality can be internalized in the sense that the producer of the externality is also its consumer. Finally, Coase's famous theorem (1960) states that externalities will not occur provided that property rights are adequately defined, enforced and exchangeable and that there are no transaction costs. 
A further remedy for the externality problem lies outside the realm of public policy. A consumer boycott can lead to an environmentally harmful product being withdrawn and replaced by a green product - often at a higher price. In so doing, the externality is internalized and the cost of the transaction is borne only by the parties to the contract. This is exactly what occurred in the Netherlands with a boycott of aerosols containing chloroflurocarbons (CFCs) which deplete the ozone layer (Simon, 1992: 269).

This last remedy links the concept of negative externalities to that of price premia for green products. As Simon points out,

'(t)he ultimate measure of environmental commitment is clearly the consumer's willingness to pay ... a green premium on an eco-safe product' (1992: 276).

A number of authors have reported on these premia, including Cavanaugh (1993), Davis (1991), Prokop (1993), Thomas (1989), Vandermerwe \& Oliff (1990) and Wasik (1992). The reported premia range from a low of about $5 \%$ (Davis, 1991: 16) to a high of between 15 and $50 \%$ (Vandermerwe \& Oliff, 1990: 11).

Reported premia are probably inaccurate as a result of the research methodology adopted in previous studies. The existence and/or amount of a premium is normally calculated on the basis of one of three questions posed to consumers:

1. Are you willing to pay more for a green product?

2. Are you willing to pay $x$ percent more for a green product?

3. How much more are you willing to pay for a green product?

Merely asking a consumer the price premium they are willing to pay is insufficient. This question in no way manages to capture the decision process and trade-offs engaged in by the consumer when choosing between a green and non-green product. Furthermore, this technique increases the respondent's tendency to engage in socially desirable behaviour. While no one can be certain of the extent of premium overstatement, Celente (quoted in Wasik, 1992: 16) goes so far as to state that 'marketers who believe ... consumers are willing to pay an environmental premium will suffer financially'.

\section{Market segmentation}

It seems fairly obvious that consumer willingness to pay a premium for a green product may vary by segment. The consumer characteristics that influence environmental concern is one of the consistent themes in the literature. Table 1 contains a summary list of these characteristics.

The hypothesized relationship between each of these variables and social responsibility/green commitment is briefly discussed below.

\section{Age}

Anderson \& Cunningham (1972) find an inverse relationship between age and social consciousness but not at a statistically significant level. In a later replication and extension, Kinnear, Taylor \& Ahmed (1974) deliver the same finding.

\section{Children}

Thomas (1989: 116) states that the presence of children in the household increases the consumer's willingness to take action
Table 1 List of variables impacting upon social responsibility or green commitment

\begin{tabular}{|c|c|}
\hline Variable & Study \\
\hline Age & $\begin{array}{l}\text { Anderson \& Cunningham, } 1972 \\
\text { Kinnear. Taylor \& Ahmed. } 1974 \\
\text { Wasik, } 1992\end{array}$ \\
\hline Children & $\begin{array}{l}\text { Kinnear, Taylor \& Ahmed, } 1974 \\
\text { Murphy, Kangun \& Locander, } 1978 \\
\text { Thomas, } 1989\end{array}$ \\
\hline Education & $\begin{array}{l}\text { Kinnear. Taylor \& Ahmed, } 1974 \\
\text { Murphy, Kangun \& Locander. } 1978 \\
\text { Roper, } 1990 \\
\text { Simmons, } 1992 \\
\text { Wasik, } 1992\end{array}$ \\
\hline Employment & $\begin{array}{l}\text { Anderson \& Cunningham, } 1972 \\
\text { Kinnear, Taylor \& Ahmed, } 1974 \\
\text { Murphy, Kangun \& Locander. } 1978\end{array}$ \\
\hline Gender & $\begin{array}{l}\text { Murphy, Kangun \& Locander, } 1978 \\
\text { Thomas, } 1989 \\
\text { Wasik, } 1992\end{array}$ \\
\hline Income & $\begin{array}{l}\text { Adams, } 1990 \\
\text { Kinnear. Taylor \& Ahmed, } 1974 \\
\text { Murphy, Kangun \& Locander, } 1978 \\
\text { Roper, } 1990 \\
\text { Simmons, } 1992 \\
\text { Wasik, } 1992\end{array}$ \\
\hline $\begin{array}{l}\text { Race } \\
\text { Socio and psycho- } \\
\text { graphic variables }\end{array}$ & $\begin{array}{l}\text { Murphy, Kangun \& Locander, } 1978 \\
\text { Anderson \& Cunningham, } 1972 \\
\text { Kinnear, Taylor \& Ahmed, } 1974 \\
\text { Webster. } 1975\end{array}$ \\
\hline
\end{tabular}

in terms of buying green products. Both Wasik (1992: 16) and Oliver Murphy (quoted in Kreitzman, 1989: 44) concur with this statement. Kinnear et al. (1974), however, fail to find any empirical support for this relationship.

\section{Education}

In a summary of previous academic research, Murphy, Kangun \& Locander (1978: 61) report a positive relationship between level of education and environmental commitment. Simon (1992: 276) states that two large scale commercial studies (Roper in 1990 and Simmons in 1991) both confirm this result. Kinnear et al. (1974), however, find no support for this relationship.

\section{Employment}

Anderson \& Cunningham (1972) find that occupation varies directly with social responsibility scores. Kinnear et al. (1974) does not find any relationship between nature of employment and ecological concern.

\section{Gender}

Thomas (1989: 116) and Wasik (1992: 16) both state that women are generally more environmentally conscious than men. 
They fail, however, to provide any empirical evidence for their statements. Kreitzman (1989: 44) quotes a study (by the British research company Diagnostics) that provides some support for this relationship.

\section{Income}

Adams (1990: 82) and Wasik (1992: 16) state that there is a positive relationship between income and environmental concern. Two large scale commercial studies (Roper in 1990 and Simmons in 1991) also find the same linkage. These results are contradicted by Anderson \& Cunningham (1972) who find no such relationship, whilst Kinnear et al. (1974) establish a modest positive linkage.

\section{Race}

Murphy et al. (1978) remains the only study to have examined the relationship between race and socially conscious consumption. The major conclusion they draw is that "white respondents do differ from their black counterparts in environmental concerns' (Murphy, 1978: 65).

\section{Sociographic and psychographic variables}

Anderson \& Cunningham (1972); Kinnear et al. (1974); and Webster (1975) all find that these variables are generally better predictors of social consciousness than demographic variables.

\section{Market size}

Considerable work has been done in estimating the size of green market segments throughout the world with widely varying results. This is probably due to divergent definitions of green consumerism and the fact that the countries in which research has been conducted are very different. Table 2 lists the studies that have attempted to estimate green market size, the countries in which these studies were conducted, their findings, and their definition of green consumerism.

\section{Empirical research}

\section{Research methodology}

Our research methodology draws upon and extends the work of Herberger \& Buchanan (1971) by addressing the relationship between environmental information and product choice. We used deodorant aerosol cans as our physical stimuli because the debate surrounding the effects of CFCs upon the ozone layer has been widely publicized (see for example, McDaniel, 1993; McIntosh, 1991; and Simon, 1992). In addition, we assessed respondent reaction when environmentally friendly products carried higher prices. We interviewed 160 respondents in mall intercepts in the Witwatersrand region using a quota sampling technique.

A two-factor experimental design was employed: environmental friendliness of products at two levels (deodorant aerosol can displays an ozone friendly label versus deodorant aerosol can does not display an ozone friendly label); and price at four levels (a realistic base price, $5 \%$ premium, $10 \%$ premium and $15 \%$ premium). Thus, respondents were asked to rank in order of preference a total of eight cans of deodorant. Upon completion of the rank ordering, respondents completed a questionnaire indicating (in order): a 16 item 'desire for social recognition' scale; occupational status; level of education; age category; income category; and presence of young children in household. The interviewer also noted the respondent's gender and race. The desire for social recognition measures were sourced from the Personality Research

Table 2 Estimates of green markets

\begin{tabular}{|c|c|c|c|}
\hline Study & Country & Size $(\%)$ & Definition \\
\hline $\begin{array}{l}\text { Bendixen, Sandler \& Seligman, } \\
1994\end{array}$ & South Africa & 33 & $\begin{array}{l}\text { Give preference to green products over other } \\
\text { products whenever there is a choice }\end{array}$ \\
\hline Cavanaugh, 1993 & USA & $40-70$ & $\begin{array}{l}\text { Willing to pay premia of } 6-10 \% \text { for environ- } \\
\text { mentally friendly products }\end{array}$ \\
\hline Corrado, 1989 & Britain & 42 & $\begin{array}{l}\text { Consciously chosen one product over another for } \\
\text { environmental reasons }\end{array}$ \\
\hline Gallup (quoted by Thomas, 1989) & USA & 50 & Pay at least $10 \%$ more for ozone-friendly aerosols \\
\hline \multirow[t]{7}{*}{ Gallup (quoted by Simon, 1992) } & Japan & 40 & Avoided environmentally harmful products \\
\hline & USA & 57 & \\
\hline & Denmark & 65 & \\
\hline & Holland & 68 & \\
\hline & UK & 75 & \\
\hline & Canada & 77 & \\
\hline & West Germany & 81 & \\
\hline Gallup (quoted by Wasik, 1992) & USA & 90 & $\begin{array}{l}\text { Willing to make a special effort to buy products } \\
\text { from companies trying to protect the environment }\end{array}$ \\
\hline Market Research Africa, 1990 & South Africa & 53.4 & $\begin{array}{l}\text { Prepared to pay more for products which are en- } \\
\text { vironment friendlier and they display a label }\end{array}$ \\
\hline Market Research Africa, 1993 & South Africa & 50.6 & $\begin{array}{l}\text { Prepared to pay more for products which display } \\
\text { an environment friendly label }\end{array}$ \\
\hline Prokop, 1993 & USA & 78 & $\begin{array}{l}\text { Willing to pay more for products that are environ- } \\
\text { mentally benign }\end{array}$ \\
\hline
\end{tabular}


Form (Form E) developed by Jackson in 1974. The defining traits of a person with a high desire for social recognition include approval seeking, making a good impression, seeking respectability and recognition, being concerned about social propriety and behaving appropriately (Jackson, 1974). Eight of the 16 social recognition items were reverse scaled to reduce acquiescence bias. The demographic measures were sourced from South Africa's All Media and Products Survey (AMPS) which has demonstrated its validity and reliability in years of tieldwork.

\section{Analysis conducted}

Conjoint analysis was conducted on each individual's rank ordering to determine the utility (or disutility) that they would receive from consuming a green product. Louviere defines this technique as

'a generic term (used) ... to refer to a number of paradigms ... that are concerned with the quantitative description of consumer preferences or value tradeoffs' (1994: 223).

The theoretical underpinnings of the technique are based upon the work of Lancaster (1966) who demonstrated that the utility a consumer receives from a product can be decomposed into the utility received from each of the attributes that combine to constitute the product. These component utilities are known as part-worth utilities. The overall utility of an alternative can then be calculated using the basic conjoint analysis model (Malhotra, 1993: 689):

$$
\text { (X) } \sum_{i=1 j=1}^{m} \sum_{i j}^{k_{i j}} a_{i j}
$$

where:

$\mathbf{U}(X)=$ overall utility of an alternative

$a_{i j} \quad=$ the part-worth contribution or utility associated with the $j$ th level $\left(j, j=1,2, \ldots k_{i}\right)$ of the $i$ th attribute $(i, i=1,2, \ldots m)$

$\mathbf{k}_{\mathbf{i}}=$ number of levels of attribute $i$

$\mathrm{m} \quad=$ number of attributes

$x_{i j}=1$ if the $j$ th level of the $i$ th attribute is present $=0$ otherwise

This equation is subject to the constraint that:

$$
\sum_{j=1}^{k_{i}} a_{i j}=0
$$

The part-worth utility associated with the product's environmental friendliness (displays an ozone friendly label versus does not display an ozone friendly label) was aggregated with the part-worth utility associated with the product's price (realistic base price, $5 \%$ increase, $10 \%$ increase, $15 \%$ increase). This procedure produced eight total utilities for each of the 160 respondents: (green product at $0 \%, 5 \%, 10 \%$ and $15 \%$ premium; and non-green product at $0 \%, 5 \%, 10 \%$ and $15 \%$ premium)

Two regressions were run for each respondent: one on the total utilities of the green product, and one on the total utilities of the non-green product. Thus, a total of 320 regressions were run. For each respondent, we calculated the price of the green alternative at a total utility level of zero (using the $\alpha$ and $\beta$ values from the regression output) as well as the price of non-green alternative at a total utility level of zero (again using the $\alpha$ and $\beta$ values from the regression output). From these two prices, we then calculated the premium that a consumer was willing to pay for the green alternative.

Since the analysis conducted was relatively complex, it was necessary to run a validation check. The authors therefore developed an algorithm to calculate the average premium. This algorithm and its derivation are contained in the appendix. The regression technique produced an average premium of $5.9 \%$, whilst the algorithm produced an average premium of $5.5 \%$. A t-test revealed that these average premia were not significantly different at an $\alpha$-level of $0.05(t=0.57 ; p=$ 0.56 ). Despite the fact that both techniques produced similar results, it was found that the algorithm technique was not as robust as the regression technique. Therefore, all further results are based upon the latter method.

\section{Results}

Seventeen respondents were removed from the sample because an infinite positive premium was calculated for them they consistently chose green products over non-green products but their rankings in terms of price appeared to be totally random. Similarly, three respondents were removed from the sample because an infinite negative premium was calculated for them. The removal of respondents reduced the total sample size to 140 .

Table 3 presents a frequency distribution of premia calculated for respondents.

As can be seen from Table 3, a substantial proportion of respondents - about $18.13 \%$ of our total sample - priced the green alternatives at a discount to the non-green alternatives. This finding is unique and makes it difficult to directly compare our results with those of prior research. Therefore, the outputs of all further analyses are presented for both the full sample (140 respondents) and a reduced sample (114 respondents) with discount seekers removed. Table 4 presents the summary statistics for the premium distributions excluding infinite premia.

Table 3 Premium frequency distributions

\begin{tabular}{lcc}
\hline Premium & $n$ & $\%$ \\
\hline Negative infinite premium & 3 & 1.88 \\
$-30 \leq p<-20$ & 1 & 0.63 \\
$-20 \leq p<-10$ & 9 & 5.63 \\
$-10 \leq p<0$ & 16 & 10 \\
$p=0$ & 32 & 20 \\
$0 \leq p<10$ & 35 & 21.88 \\
$10 \leq p<20$ & 43 & 26.88 \\
$20 \leq p<30$ & 2 & 1.25 \\
$30 \leq p<40$ & 2 & 1.25 \\
Positive infinite premium & 17 & 10.63 \\
\hline Total & 160 & 100 \\
\hline
\end{tabular}


Table 4 Summary statistics for premium frequency distribution

\begin{tabular}{lcc}
\hline Measure & $\begin{array}{c}\text { Full } \\
\text { sample }\end{array}$ & $\begin{array}{c}\text { Reduced } \\
\text { sample }\end{array}$ \\
\hline $\mathrm{n}$ & 140 & 114 \\
Mean & 5.9 & 9.39 \\
Median & 2.36 & 3.77 \\
Standard deviation & 11.72 & 9.47 \\
Minimum value & -22.14 & 0 \\
Maximum value & 34.73 & 34.73 \\
Range & 56.87 & 34.73 \\
\hline
\end{tabular}

To determine the relationship between consumer characteristics and price premia, respondents were classified into two mutually exclusive and exhaustive groups for each variable. Table 5 presents the premium summary statistics for these variable subgroups.

We used t-tests to determine whether or not the premium means for the groups of each variable in Table 5 were different at a statistically significant level. Table 6 presents the results of the t-tests.

For the full sample, the results of the t-tests indicate that the only variable with a significant difference (at an $\alpha$-level of 0.05 ) in mean premium was race. For the reduced sample, the results indicate that the only variables with significant differences in mean premium were race (at an $\alpha$-level of 0.01 ) and education (at an $\alpha$-level of 0.05 ). These results may be due to variances in an underlying variable such as income or employment status. Therefore, two-way ANOVAs were run to test this hypothesis. However, no significant interactions were found.

\section{Discussion of results}

While many of our findings are consistent with previous research, we also obtained some results that were totally unexpected. Obviously, the most surprising result is the existence of a substantial proportion of respondents, about $18.13 \%$ of our total sample, who seek a discount when purchasing green products. This result has not been found in any prior research. The only explanation we can offer is that these respondents probably perceive green products as being less effective than their non-green counterparts. We also found that $20 \%$ of our total sample did not respond to the difference between green and non-green products. These respondents were not willing to pay a premium for either of the options. These two results confirm Kinnear et al.'s (1974: 23) conclusion that there may well exist 'a substantial segment that exhibits little or no concern about the pollution aspects of products'.

Approximately $61.88 \%$ of our sample were willing to pay a premium for green products. This result is in the range indicated by previous research. Our mean premium of $5.5 \%$ (for the full sample) is at the bottom of the range of premia found in previous studies. It is necessary to bear in mind, however, that this figure is skewed downwards by the inclusion of respondents with negative premia. On the other hand, our mean premium of $9.39 \%$ (for the reduced sample) is consistent with the results of previous studies.

Prior research has also not mentioned consumers who state they are willing to pay a positive infinite premium for green products. Whilst this result may be an artifact of our research methodology, it is nevertheless intuitively pleasing - although these consumers may not have the money to purchase more expensive green products, we believe they cannot be persuaded to buy non-green products at any price. When faced with the choice of a relatively cheap non-green product and a green product at a substantial premium they would probably choose not to purchase either of the alternatives. The same

Table 5 Premium summary statistics for subgroups

\begin{tabular}{|c|c|c|c|c|c|c|c|}
\hline \multirow[t]{2}{*}{ Variable } & \multirow[t]{2}{*}{ Category } & \multicolumn{3}{|c|}{ Full sample } & \multicolumn{3}{|c|}{ Reduced sample } \\
\hline & & $\mathbf{n}$ & mean & s.d. & $\mathbf{n}$ & mean & s.d. \\
\hline \multirow[t]{2}{*}{ Age } & $<35$ years & 80 & 7.4 & 11.78 & 68 & 10.32 & 9.80 \\
\hline & $\geq 35$ years & 59 & 3.6 & 11.28 & 45 & 7.70 & 8.72 \\
\hline \multirow[t]{2}{*}{ Children } & Children in household & 67 & 5.57 & 12.91 & 53 & 10.02 & 9.93 \\
\hline & No children in household & 71 & 6.08 & 10.54 & 59 & 8.76 & 9.01 \\
\hline \multirow[t]{2}{*}{ Education } & At most some high school & 63 & 4.65 & 11.42 & 54 & 7.36 & 9.46 \\
\hline & At least high school completed & 75 & 6.79 & 11.95 & 58 & 11.17 & 9.15 \\
\hline \multirow[t]{2}{*}{ Employment } & Employed full time & 88 & 7.08 & 10.46 & 74 & 9.55 & 9.14 \\
\hline & Not employed full time & 49 & 3.65 & 13.61 & 37 & 9.16 & 10.17 \\
\hline \multirow[t]{2}{*}{ Gender } & Male & 73 & 7.71 & 10.57 & 62 & 10.15 & 9.23 \\
\hline & Female & 67 & 3.94 & 12.65 & 52 & 8.48 & 9.76 \\
\hline \multirow[t]{2}{*}{ Income } & $<$ RI500 per month & 72 & 6.38 & 11.37 & 64 & $8.5 !$ & 9.81 \\
\hline & $\geq$ RI500 per month & 62 & 5.57 & 11.96 & 46 & 10.50 & 8.84 \\
\hline \multirow[t]{2}{*}{ Race } & Black & 74 & 4.07 & 10.42 & 63 & 6.52 & 8.69 \\
\hline & White & 66 & 7.96 & 12.8 & 51 & 12.93 & 9.26 \\
\hline \multirow[t]{2}{*}{ Social index } & $<0.5$ & 41 & 6.94 & 12.82 & 33 & 11.35 & 9.42 \\
\hline & $\geq 0.5$ & 99 & 5.48 & 11.27 & 81 & 8.58 & 9.43 \\
\hline
\end{tabular}


Table 6 Results of t-tests

\begin{tabular}{lcccccc}
\hline & \multicolumn{3}{c}{ Full sample } & \multicolumn{3}{c}{ Reduced sample } \\
\hline Variable & df & $\mathrm{t}$ value & $\mathrm{p}$ value & $\mathrm{df}$ & $\mathrm{t}$ value & $\mathrm{p}$ value \\
\hline Age & 137 & 1.91 & 0.05 & 111 & 1.45 & 0.15 \\
Children & 136 & -0.25 & 0.8 & 110 & 0.71 & 0.48 \\
Education & 136 & -1.06 & 0.28 & 110 & -2.17 & $0.03^{*}$ \\
Employment & 135 & 1.64 & 0.1 & 109 & 0.21 & 0.84 \\
Gender & 138 & 1.91 & 0.05 & 112 & 0.94 & 0.35 \\
Income & 1.32 & 0.40 & 0.68 & 108 & -1.09 & 0.28 \\
Race & 138 & -1.98 & $0.04 *$ & 112 & -3.81 & $0.00^{* *}$ \\
Social index & 1.38 & 0.66 & 0.5 & 112 & 1.42 & 0.16 \\
\hline *Significant at an $\alpha$-level of 0.05 & & & & \\
**Significant at an $\alpha$-level of 0.01. &
\end{tabular}

reasoning probably holds true for respondents for whom a negative infinite premium was calculated.

For the full sample, the only variable with a significant difference (at an $\alpha$-level of 0.05 ) in mean premium is race. Whites are willing to pay a mean premium of $7.96 \%$ whilst Blacks are willing to pay a mean premium of only $4.07 \%$. For the reduced sample, race is again significant, this time at an $\alpha$-level of 0.01 . Once more, Whites are willing to pay a greater premium than Blacks - $12.93 \%$ compared to $6.52 \%$. These results are consistent with those of Murphy et al. (1978) who found that White consumers are more environmentally conscious than their Black counterparts. South Africa's history is one of racial inequality and it is possible that the difference in mean premium may result from variances in an underlying variable such as income or employment status. The fact that the two-way ANOVAs show no significant interactions refutes this explanation. Corder (1991) provides a possible answer. Under Apartheid, Blacks were forced to live in generally squalid townships. As a result, environmental concern in this group is centred around the more immediate issue of litter as opposed to the more distant concept of ozone depletion. Corder (1991: 8) states that $69 \%$ of Blacks are aware of litter as a global issue (in comparison to $91 \%$ of Whites), but only $8 \%$ of Blacks are aware of the depletion of ozone as a global issue (in comparison to $83 \%$ of Whites).

For the reduced sample, mean differences in premium according to educational level are also significantly different at an $\alpha$-level of 0.05 . Respondents with at most some high school education are willing to pay an average premium of $7.36 \%$. This premium increases to $11.17 \%$ amongst respondents who have at least completed high school. This result suggests that education plays a vital role in increasing levels of environmental awareness.

\section{Conclusion}

The major conclusion that can be drawn from this study is that great disparity exists in consumer willingness to pay a premium for green products. Some consumers demand a discount for these products, others state that they are willing to pay an infinite premium, and some do not respond to the difference between green and non-green products. The major implication of these findings is that the onus rests upon the marketer to practice segmentation and target the green consumer. In South Africa at least, this consumer is probably White and well educated but this may change rapidly in the future. Certainly, further cross-cultural replication is needed before a more definitive conclusion can be drawn. It is hoped, however, that further research in this field will use methodologies that approximate more closely the consumer's decision and trade-off processes when choosing between green and non-green products.

\section{Acknowledgement}

The authors wish to express their gratitude to: Sigma Assessment Systems for permission to use the social recognition test scales; colleagues who provided valuable input, in particular, C. Corder, S. Davidson, J. de Villiers, N. Higgs and M. Polonsky; and S. da Silva and S. Meyer for assistance with the data analysis.

\section{References}

Adams, R. 1990. 'The greening of consumerism', Accountancy, pp. 81-82.

Anderson, W.T. \& Cunningham, W.H. 1972. 'The socially conscious consumer', Journal of Marketing, 36(3): 23-31.

Bell, M.L. \& Emory, C.W. 1971. 'The faltering marketing concept', Journal of Marketing, 35(4): 37-42.

Bendixen, M.T., Sandler, M. \& Seligman, D. 1994. 'Consumer perceptions of environmentally friendly products', South African Journal of Business Management, 25(2): 59-64.

Cavanaugh, H.A. 1993. 'Power marketing', Electrical World, pp. · 19-20.

Coase, R.H. 1960. 'The problem of social cost', Journal of Law and Economics, 3: 1-44.

Corder, C.K. 1991. 'Project ECOS - the South African national environmental conservation survey', Southern Africa International Conference on Environmental Management.

Corrado, M. 1989. 'The greening consumer in Britain. WAPOR conference, Stockholm.

Davis, J. 1991. 'A blueprint for green marketing', The Journal of Business Strategy, 12(4): 14-17.

Herberger, R.A. \& Buchanan, D.T. 1971. 'The impact of concern for ecological factors on consumer attitudes and buying behaviour'. In Allvine, F.C. (ed.). Marketing in motion: relevance in marketing. Chicago: American Marketing Association, pp. 644-646.

Hirshleifer, J. 1988. Price theory and applications. 4th ed. Englewood Cliffs, New Jersey: Prentice Hall.

Jackson, D.N. 1974. Personality research form E manual. United States of America: Research Psychologists Press Inc.

Kinnear, T.C., Taylor, J.R. \& Ahmed, S.A. 1974. 'Ecologically concerned consumers: who are they?', Journal of Marketing, 38(2): $20-24$.

Kotler, P. 1976. Marketing management: analysis, planning, and control. 3rd ed. Englewood Cliffs, New Jersey: Prentice-Hall.

Kreitzman. L. 1989. 'Green with guilt', Marketing, pp. 43-44.

Lancaster, K. 1966. 'A new approach to consumer theory', Journal of Political Economy, 74(1): 132-157.

Louviere, J.J. 1994. 'Conjoint analysis'. In Bagozzi, R.P. (ed.). Advanced methods of marketing research. Cambridge, Massachusetts: Blackwell, pp. 223-259.

Malhotra, N.K. 1993. Marketing research: an applied orientation. Englewood Cliffs, New Jersey: Prentice-Hall.

Market Research Africa. 1990. Project Ecos. Johannesburg: Market Research Africa.

Market Research Africa. 1993. Project Ecos. Johannesburg: Market Research Africa. 
McDaniel, S.W. \& Rylander, D. 1993. 'Strategic green marketing', Journal of Consumer Marketing, 10(3): 4-10.

McIntosh. A. 1991. 'The impact of environmental issues on marketing and politics in the 1990s', Journal of the Market Research Society, 33(3): 205-217.

Murphy, P.E., Kangun, N. \& Locander, W.B. 1978. 'Environmentally concerned consumers -Racial variations', Journal of Marketing, 42(4): 61-66.

Prokop, M.K. 1993. Managing to be Green. San Diego: Pfeiffer. Roper Organisation. 1990. The environment: public attitudes and individual behaviour. Study commissioned by Johnson, S.C. and Son. Inc.

Simmons Market Research Bureau. 1992. 'Earth calling: is America listening?' . Simmons Media and Markets 199I Syndicated Survey. New York: Simmons Market Research Bureau.

Simon, F.L. 1992. 'Marketing green products in the Triad', The Columbia Journal of World Business, 27(3): 268-285.

Thomas, H. 1989. 'By appointment to the green consumer', Accountancy, pp. 116-117.

Vandermerwe. S. \& Oliff, M.D. 1990. 'Consumers drive corporations green', Long Range Planning, 23(6): 10-16.

Wasik. J. 1992. 'Market is confusing, but patience will pay off', Marketing News, pp. 16-17.

Webster, F.E. 1975. 'Determining the characteristics of the socially conscious consumer', The Journal of Consumer Research, 2: 188196.

\section{Appendix}

The algorithm used to calculate the premia is given by:

$$
p=\left(\left[\frac{\left(a_{g}+a_{p j}-m_{g} p_{g j}\right) m_{n g}}{\left(a_{n g}+a_{p j}-m_{n g} p_{n g j}\right) m_{g}}\right]-1\right) * 100
$$

where:

$\mathrm{p}=$ premium of a green product over a non-green product

$\mathrm{a}_{\mathrm{ni}}=$ part-worth utility of price at the $j$ th level

$a_{g}=$ part-worth utility associated with the product being green

$a_{n g}=$ part-worth utility associated with the product being non-green

$\mathrm{m}_{\mathrm{g}}=$ gradient of the total utility function for a green product

$\mathrm{m}_{\mathrm{ng}}=$ gradient of the total utility function for a non-green product

$P_{\mathrm{gj}}=$ price of a green product at the $j$ th level

$\mathrm{p}_{\mathrm{ng}}=$ price of a non-green product at the $j$ th level

When total utility equals zero, the premium of a green product over a non-green product is given by:

$$
p=\left[\frac{p_{g}-p_{n g}}{p_{n g}}\right] * 100
$$

where:

$\mathrm{p}_{\mathrm{g}}=$ price of a green product when total utility equals zero $\mathrm{p}_{\mathrm{ng}}=$ price of a non-green product when total utility equals zero
This equation simplifies to:

$$
p=\left[\frac{p_{k}}{p_{n g}}-1\right] * 100
$$

It is then necessary to solve for $p_{\mathrm{g}}$ and $p_{\mathrm{ng}}$.

The total utility for a green product can be represented by:

$T U_{x p}=m_{\mathrm{e}} p_{\mathrm{z}}+c_{\mathrm{g}}$

where:

$\mathrm{TU}_{\mathrm{gp}}=$ total utility of a green product

$c_{g}=$ total utility of a green product when price equals zero.

For the sake of simplicity, let us solve for $p_{\mathrm{g}}$ when total utility equals zero. This is simply:

$$
p_{k}=-\frac{c_{k}}{m_{g}}
$$

Similarly, the price of a non-green product when total utility equals zero is given by:

$$
p_{n g}=-\frac{c_{n g}}{m_{n g}}
$$

where:

$c_{n g}=$ total utility of a non-green product when price equals zero

Thus substituting (7) and (8) into (5), and with some re-arranging, we get:

$$
p=\left[\frac{c_{R} m_{n g}}{c_{n g} m_{R}}-1\right] * 100
$$

We still need to solve for $c_{\mathrm{g}}$ and $c_{\mathrm{ng}}$. Re-arranging (6) we get:

$$
c_{s}=T U_{k p}-m_{g} p_{k}
$$

But, from (1) we also know that the total utility of a green product at the jth price level can be given by:

$$
T U_{k p j}=a_{k}+a_{p j}
$$

where:

$\mathrm{TU}_{\mathrm{gn}}=$ total utility of a green product at the jth price level Thus by specifying $j$ and substituting (11) into (10) we get:

$$
c_{k}=a_{g}+a_{p j}-m_{g} p_{g j}
$$

And similarly:

$$
c_{n g}=a_{n g}+a_{p j}-m_{n g} p_{n j j}
$$

Finally, substituting (12) and (13) into (9) we get:

$$
p=\left(\left[\frac{\left(a_{g}+a_{p j}-m_{g} p_{g j}\right) m_{n g}}{\left(a_{n g}+a_{p j}-m_{n g} p_{n g j}\right) m_{g}}\right]-1\right) * 100
$$

